\title{
CAN OTHER DISCIPLINES SUPPORT OCCUPATIONAL HEALTH AND SAFETY EFFORTS? IMPORTANCE OF SAFETY CULTURE: A STUDY ON A COAL MINE INSTITUTION
}

\author{
[Mohou ostatní disciplíny podporovat úsilí o pracovní zdraví a bezpečnost? \\ Důležitost bezpečnosti: studie uhelného dolu] \\ Burcu Akdeniz ${ }^{1}$, Ceren Giderler ${ }^{2}$, N. Derya Ergun Özler ${ }^{3}$ \\ ${ }^{I}$ Dumlupinar University, DPU Merkez Kampus, YDYO, B Blok No: 101, Kütahya, Turkey \\ Email: burcu.akdeniz@dpu.edu.tr \\ ${ }^{2}$ Dumlupınar University, DPU Merkez Kampus, İIBF, İşletme Bölümü, Kütahya, Turkey \\ Email: ceren.giderler@dpu.edu.tr \\ ${ }^{3}$ Dumlupınar University, DPU Merkez Kampus, IIBF, İsletme Bölümü, Kütahya, Turkey \\ Email:derya.eozler@dpu.edu.tr
}

\begin{abstract}
Human behaviour is strongly influenced by the culture they live in. Therefore, if safety is a priority in a company's culture and this norm is internalized by every member of this organization, elimination of all types of unsafe behaviour would be possible. This aspect of organizational culture is called safety culture. In order to evaluate the safety culture in an organization, one of the useful tools is application of a safety culture survey. Application of a safety culture survey among a company's workers and managers would supply the management with valuable data concerning the safety culture perception of the organization members. Thus, the results from analyses of this data including the demographical features of the organization members would help the managers and OHS professionals design more effective activities to prevent workplace accidents. This paper aims at explaining the importance of safety culture and its contribution to OHS efforts. An empirical study applied at a large state owned coal mine institution located in Kütahya province in Turkey using a safety culture survey tool will be presented as an example of how a safety culture survey is implemented and evaluated for a company with high level of risks. Results of the analyses revealed that the participants' safety culture levels have statistically significant difference for age, education level, work experience, duty at work groups, and the state of having been exposed to any nearmiss accidents. However, no statistically significant difference was determined for their marital status, position at work, the state of having been exposed to any occupational accidents in any workplace and the state of having been exposed to any occupational accident in their current workplace.
\end{abstract}

Keywords: demographic features, human factor, occupational accidents, safety culture, unsafe behaviour.

JEL classification: M1, M12, M14, J28

Doručeno redakci: 7.8.2018; Recenzováno: 21.8.2018; 3.9.2018; Schváleno k publikování: 21.11.2018

\section{Introduction}

Growing importance of occupational health and safety (OHS) around the world and in Turkey necessitates contribution of various disciplines such as human resources management, business administration, preventive medicine, behavioural sciences, psychology and sociology. Improvements in production technologies and technical precautions, together with changing legal sanctions have resulted in significant progress in OHS conditions. However, occupational accidents are still a problem of businesses. This phenomenon can be explained with the human factor basically. Despite the precautions and procedures established against workplace accidents, employees usually ignore safety rules and perform unsafe behaviour when they are not supervised. 
Besides, in some situations such as limited time for production and costs of safety precautions that seem to be high, managers and/or employers tend to ignore importance of safety. Although they are all aware of the risks they are taking and the possible costs of their behaviour, their attitude hardly changes. This deep problem concerning human behaviour can be solved using one strong tool: organizational culture. The aspect of the organizational culture which represents the safety perceptions of the employees is called safety culture.

Following the catastrophic SOMA coal mine accident, which took place in the western part of Turkey in year 2013 and caused death of 311 coal miners, the legal conditions concerning workplace safety have dramatically improved in Turkey. Besides, thanks to technological developments, more sophisticated tools, machines and methods are employed in workplaces for preventing accidents. However, the rate of workplace accidents unfortunately is not dropping in parallel with these developments. To explain the reason for this situation, experts usually refer to human factor. Studies have shown that about $80 \%$ of occupational accidents are caused by human error and most of these cases are related with unsafe or risk taking behaviour of individuals. Moreover, there are some studies stating that the sincerity of efforts and degree of importance given to safety issues by both the managers and workers is shaped by the culture of that organization (Potter 2004).

This paper aims at revealing the importance of safety culture for the success of OHS efforts and how the disciplines of business administration and human resources management can contribute to occupational health and safety efforts using safety culture as a tool. Safety culture is a feature of an organization that needs to be focused on in order to be used as a basis for OHS efforts. Just like organizational culture, safety culture can be manipulated for creating a better safety climate where safe behaviour is perceived as a norm among employees. By this research, it was determined that in order to design safety training and other OHS activities concerning the employees, their demographic features and their needs should be determined beforehand. This can be facilitated in an organization by the efforts of the human resources professionals, who are well informed about the demographical features of the employees.

\section{Literature Review}

Occupational health and safety (OHS) is generally defined as the science of the anticipation, recognition, evaluation and control of hazards arising in or from the workplace that could impair the health and well-being of workers, taking into account the possible impact on the surrounding communities and the general environment (Alli 2008, p. 7). The legal framework concerning OHS standards in Turkey is shaped by the Law of Occupational Health and Safety Numbered 6331 and other related laws and regulations together with some international contracts such as ILO (International Labour Organization) and WHO (World Health Organization) conventions.

In order to set safety as a core value of an organization it is necessary to focus on the organizational culture where all the values and norms of an organization underlie. Organizational culture is defined by Hofstede (1991, p. 18) as the way in which members of an organization relate to each other, their work and the outside world in comparison to other organisations, in other words "the software of the mind". Peters and Waterman define organizational culture as a structure composed of stories, slogans, myths, beliefs and norms formed by shared and dominant values within an organization that reflect in symbolic ways among the members of the organization (1982, cited in İra and Aksu 2009, p. 45). Koçel (2011, p. 135-136) defines culture as the total entity composed of 
learned and shared values beliefs, behaviour and attitudes and all the symbols with specific meanings. He considers the culture of the society as the macro-superior culture and the organizational culture as a micro-subculture. Also, he states that the organizational culture regulates the behaviour within an organization and defines the meaning of right or wrong, the important aspects of life and legal behaviour.

The aspect of organizational culture concerning occupational safety is named safety culture. Glendon and Stanton (2000, p. 193) state that safety culture is composed of attitudes, behaviour, norms and values concerning safety together with personal responsibilities and characteristics of human resources such as education and development. Guldenmund (2000, p. 215) defines safety culture as the features of an organization which influence the behaviour and attitudes which increase or decrease risks. The main aim of safety culture is to reflect the priority of safety in all aspects of life. As a result increasing the frequency of safe behavior and eliminating unsafe behavior, consequently reaching high levels of safety performance- maybe the "zero-accident-rate" level- is in the focus of all safety culture efforts (Akdeniz 2018).

Research has revealed that the number of the occupational accidents caused by human error is much greater than those caused by environmental or technical factors. Human error is mostly related with risky/unsafe behavior of the workers. Geller (2005, p. 552-554) considers the at-risk behavior of the employees in two groups as knowingly at-risk and unknowingly at-risk behavior. The intervention needed for the unknowingly at-risk behavior, which is normally detected by observation method, includes structured feedback, safety training and similar methods. However, the knowingly at-risk behavior consists of the unsafe behavior of workers who "prefer" to act like that consciously in order to work more comfortably or productively. In this case, they calculate the risk and ignore one or more safety rules, which indicates lack of a strong safety culture. If safety is an internalized priority a worker will not violate any safety rule consciously.

Tüzüner and Özaslan (2011) studied safety culture perceptions of hospital employees, including nurses, doctors, cleaning personnel and administrative staff, considering their demographical features. They determined statistically significant differences in terms of safety culture perceptions for the employees" "staff categories" and "departments" they work at. However, no statistically significant difference was detected in terms of their gender, age, educational level groups, total job experience and employment term in their current work place. They concluded that it would be beneficial for improving the safety culture climate of organizations if the human resources departments of the hospitals designed special safety training and orientation activities.

Lin et al. (2008) in their study, examined safety climate perceptions of employees from various sectors, namely cement plant, chipboard production, shoe manufacturing and oil refinery. The number of the participants was 1026 and the aim of the study was to develop a safety climate survey tool for China. Differences in terms of safety climate perceptions as for demographical features of the participants were analyzed. Comparisons of safety climate scores among various groups by age, years of work experience, accident involvements, and organizations were used to test discriminant validity. The safety climate questionnaire loading on components revealed seven different factors: safety awareness and competence, safety communication, organizational environment, management support, risk judgment, safety precautions, and safety training. Statistically significant difference was determined for work experience for safety awareness, safety communication and safety training dimensions. The groups concerning the experience of having an occupational in the 
current workplace, at any workplace and state of having a nearmiss accident were also analyzed and some statistically significant differences were reported.

\section{Methodology}

This paper will initially explain the concept of safety culture within the framework of organizational culture. Following the brief literature review, an empirical study will be presented. The study was performed using a safety culture survey tool developed by Dursun (2012) and ten demographical questions. The survey was performed in a large state owned coal mine institution located in Kütahya province, namely TKİ-Garp Linyitleri İşletmesi. Considering the large number of employees of the institution which is about 1800 people, a sample of 333 people was needed due to $10 \%$ error margin and 5\% significance level (Baş 2001, p. 46). Therefore, in order to increase reliability, 1000 survey forms were distributed among members of the whole institution employed in each department. Only 704 forms were returned. After eliminating the empty and incomplete forms a total of 529 forms were included in the analyses. Following the determination of percentages concerning demographical features of the participants, MANOVA and independent samples t-test were performed in order to determine the relationship between some demographical features of the participants and their safety culture levels. The safety culture assessment tool was originally composed of 8 safety culture dimensions. However, as the dimensions of managers' safety commitment and priority of safety came together as one dimension and the dimensions of safety training and safety communication came together as one dimension the factor analyses revealed 6 dimensions for the chosen population in this study. The safety dimensions in this study are given in Table 1.

Table 1: Safety culture dimensions

\begin{tabular}{lcc}
\hline Safety Culture Dimensions & $\begin{array}{c}\text { Total Variance } \\
\text { Explained \% }\end{array}$ & Cronbach's Alpha $(\alpha)$ \\
\hline 1. Managers' safety commitment and priority of safety & 16.36 & .93 \\
\hline 2. Safety training and communication & 14.78 & .92 \\
\hline 3. Employees' involvement & 11.70 & .87 \\
\hline 4. Safety awareness and competency & 10.54 & .86 \\
\hline 5. Fatalism & 6.49 & .78 \\
\hline 6. Reporting culture & 6.34 & .80 \\
\hline Source: Adapted from Akdeniz (2018, p. 166-168) & &
\end{tabular}

The demographical questions included gender, age, marital status, education level, term of employment, position at work (manager or not), duty at work and 3 yes-no questions concerning the participants' experience of occupational accidents. These 3 questions were as follows:

1. Have you ever had an accident at any workplace?

2. Have you ever had an accident in this institution?

3. Have you ever had a near-miss accident in this institution?

The data collected through survey was first entered to SPSS 18 programme then; MANOVA and t-test were applied. As a result, for some of the safety culture dimensions, statistically significant relationship was determined with some of the demographical features of the participants.

\section{Results and Discussion}

The population is mostly composed of male and married individuals who are employed at worker status, which was reflected in the statistics of the sample as follows. The demographic factors of the study were gender, age, marital status, education level, term of employment, position at work (manager or not), duty at work and participants' experience of occupational accidents. As seen in 
Table 2, education level of the participants is higher than expected with almost half of the population who have graduated from high school and about $38 \%$ with a university degree. In coal mines, the education levels of employees used to be lower in the past, but due to the advances in the technology used in mines, now workers with higher education levels are needed. In literature, quite a lot of risk factors are listed for coal mines. However the number of participants declaring that they had an accident in their working life or this institution is less than half of those who said no to the related questions. Only the ratio of those who have near-miss experience is a bit higher, but still much less than the ratio of the participants who stated that they had never had a near-miss accident. This result can either be explained with a good safety environment for the institution or reluctance of the participants to tell the truth about occupational accidents that take place in their institution.

Table 2: Demographic Features of the Participants

Age

\begin{tabular}{|c|c|c|}
\hline Categories & $\mathbf{N}$ & $\%$ \\
\hline $21-25$ & 35 & 6,6 \\
\hline $26-30$ & 103 & 19,5 \\
\hline $31-35$ & 112 & 21,2 \\
\hline $36-40$ & 87 & 16,4 \\
\hline $41+$ & 192 & 36,3 \\
\hline Total & 529 & 100,0 \\
\hline \multicolumn{3}{|l|}{ Gender } \\
\hline Categories & $\mathbf{N}$ & $\%$ \\
\hline Female & 35 & 6,6 \\
\hline Male & 494 & 93,4 \\
\hline Total & 529 & 100,0 \\
\hline \multicolumn{3}{|c|}{ Term of Employment } \\
\hline Categories & $\mathbf{N}$ & $\%$ \\
\hline $1-3$ years & 144 & 27,2 \\
\hline 4-6 years & 166 & 31,4 \\
\hline $7-9$ years & 45 & 8,5 \\
\hline 10 years and more & 174 & 32,9 \\
\hline Total & 529 & 100,0 \\
\hline \multicolumn{3}{|l|}{ Position at Work } \\
\hline Categories & $\mathbf{N}$ & $\%$ \\
\hline Manager & 52 & 9,8 \\
\hline Personnel & 477 & 90,2 \\
\hline Total & 529 & 100,0 \\
\hline
\end{tabular}

\begin{tabular}{lll}
\hline \multicolumn{3}{l}{ Experience of Having a Near-Miss Accident in } \\
\hline Categories & N & \% \\
\hline Yes & 192 & 36,3 \\
No & 337 & 63,7 \\
\hline Total & 529 & $\mathbf{1 0 0 , 0}$
\end{tabular}

Education Level

\begin{tabular}{lll}
\hline Categories & N & \% \\
\hline Primary and secondary school & 34 & 6,4 \\
High School & 293 & 55,4 \\
University degree and post-graduate & 202 & 38,2
\end{tabular}

\begin{tabular}{lll}
\hline Total & $\mathbf{5 2 9}$ & $\mathbf{1 0 0 , 0}$ \\
\hline Marital Status & & \\
\hline Categories & $\mathbf{N}$ & $\mathbf{\%}$ \\
\hline Married & 427 & 80,7 \\
Single & 102 & 19,3 \\
\hline Total & $\mathbf{5 2 9}$ & $\mathbf{1 0 0 , 0}$ \\
\hline & & \\
\hline Duty at Work & & \\
\hline Categories & $\mathbf{N}$ & $\mathbf{\%}$ \\
\hline Worker & 406 & 76,7 \\
Administrative Staff & 67 & 12,7 \\
Manager & 20 & 3,8 \\
Engineer & 36 & 6,8 \\
\hline Total & $\mathbf{5 2 9}$ & $\mathbf{1 0 0 , 0}$ \\
\hline
\end{tabular}

\begin{tabular}{lll}
\hline \multicolumn{3}{l}{ Experience of Having an Accident at Any } \\
\hline Categories & $\mathbf{N}$ & $\mathbf{\%}$ \\
\hline Yes & 151 & 28,5 \\
No & 378 & 71,5 \\
\hline Total & $\mathbf{5 2 9}$ & $\mathbf{1 0 0 , 0}$ \\
\hline
\end{tabular}

\begin{tabular}{lll}
\hline \multicolumn{3}{l}{ Experience of Having an Accident in This } \\
\hline Categories & $\mathbf{N}$ & $\mathbf{\%}$ \\
\hline Yes & 107 & 20,2 \\
No & 422 & 79,8 \\
\hline Total & $\mathbf{5 2 9}$ & $\mathbf{1 0 0 , 0}$
\end{tabular}

Source: Adapted from Akdeniz (2018, p. 165)

As for the age and term of employment in this institution, results revealed that the largest proportion of the participants were over the age of 40 and have been employed there for more than 10 years. These results can be interpreted with low turn-over rates and long term employment for the institution. Considering the long history of the institution and the fact that it has always been a state 
owned enterprise, these results are expected. Besides, based on these results it is possible to state that this population is a proper place to study culture.

Analyses revealed that demographical features, in other words personal characteristics, of the participants affect their level of safety culture perceptions. That is, some certain groups have stronger perception of some certain dimensions of safety culture compared to other groups. However, for this institution, some demographical features were determined not to cause any statistically significant difference between groups in terms of dimensions of safety culture. According to the analysis results, these ineffective features are gender, marital status, position at work (being a manager or not), and the state of having an accident in this workplace or in any other workplace $(\mathrm{p}>.05)$. Those features of the participants that caused statistically significant differences between the groups were age, education level, term of employment, duty at work and the state of having experienced a near miss accident at this institution. The detailed report of the analysis results are given below in Tables 3 to 7 together with their interpretations.

Statistically significant difference was determined between the age groups of the participants as a result of the conducted t-test. The results are given in Table 3.

Table 3: Participants' Age and Safety Culture Dimensions

\begin{tabular}{llc}
\hline & \multicolumn{2}{l}{ Employees' involvement } \\
\hline Age Group & Mean & SD \\
\hline $\mathbf{2 1 - 2 5}$ & 3,33 &, 87 \\
\hline $\mathbf{2 6 - 3 0}$ & 2,98 &, 98 \\
\hline $\mathbf{3 1 - 3 5}$ & 3,08 &, 95 \\
\hline $\mathbf{3 6 - 4 0}$ & 3,09 &, 96 \\
\hline $\mathbf{4 1 +}$ & 3,36 &, 89 \\
\hline
\end{tabular}

Source: Adapted from Akdeniz (2018, p. 177)

Only the averages of the Age group 26-30 are significantly lower than the averages of the age group $40+$ in Employees' involvement (Pillai's Trace $=.08, \mathrm{~F}_{(24,2044)}=1.58, \mathrm{p}<.05$, partial $\eta^{2}=.02$ ). This can be interpreted as the older group feel that they have adequate chances to take place in decision making concerning safety issues but the young participants are not content with their involvement capacity.

Statistically significant difference was determined between the education level groups of the participants as a result of MANOVA. The results are given in Table 4.

Table 4: Participants' Education Level and Safety Culture Dimensions

\begin{tabular}{lllll}
\hline & \multicolumn{2}{c}{$\begin{array}{c}\text { Employees' } \\
\text { involvement }\end{array}$} & \multicolumn{2}{c}{ Fatalism } \\
\hline Education Level & Mean & SD & Mean & SD \\
\hline Primary and Secondary School & 3,58 &, 67 & 3,19 &, 83 \\
\hline High School & 3,24 &, 98 & 2,53 &, 93 \\
\hline University degree and post-graduate & 3,02 &, 90 & 2,36 &, 89 \\
\hline
\end{tabular}

Source: Adapted from Akdeniz (2018, p. 177)

Results concerning Education level revealed that the group with the highest level of education had significantly lower perception concerning Employees' involvement compared to the other two groups of education (Pillai's Trace $=.09, \mathrm{~F}_{(12,1022)}=3.76$, partial $\eta^{2}=.04$ ). Between the groups of primary school and high school graduates no significant difference was detected. Apparently, the 
group with university education is not content with the opportunities given to them in terms of getting involved in decision making mechanisms concerning safety issues.

As for Fatalism, the group with primary school education had significantly higher perception concerning Fatalism compared to the other two groups. Between the two other groups with high school and university degree no significant difference was detected. This can be due to the fact that the participants of lower level of education are more prone to consider accidents as inevitable and "preordained". On the other hand, those with high school and higher education level consider the accidents as a result of human error or technical problems. Fatalism is a negative dimension of safety culture. In other words, high levels of Fatalism indicate a poor safety culture in an organization.

Considering the previous studies on safety culture in the context of high risk organizations in Turkey; Dursun (2012) who conducted a similar study at an automobile production facility determined statistically significant difference between the participants who have high level of education and those who have low level of education for all dimensions of safety culture except employees' involvement and safety awareness. Demirbilek (2005) on the other hand conducted a similar study on safety culture in a textile factory and determined statistically significant difference between education level groups for managers' safety commitment, priority of safety, safety involvement, physical stress, perceptions and cults dimensions.

Statistically significant difference was determined between the groups of participants with different terms of employment in the institution as a result of MANOVA. The results are given in Table 5.

Table 5: Participants' Term of Employment and Safety Culture Dimensions

\begin{tabular}{lllllllll}
\hline & \multicolumn{2}{c}{$\begin{array}{c}\text { Managers' safety } \\
\text { commitment and priority } \\
\text { of safety }\end{array}$} & $\begin{array}{c}\text { Safety training and } \\
\text { communication }\end{array}$ & $\begin{array}{c}\text { Safety awareness } \\
\text { and competency }\end{array}$ & $\begin{array}{l}\text { Employees' } \\
\text { Involvement }\end{array}$ \\
\hline Term of employment & Mean & SD & Mean & SD & Mean & SD & Mean. & SD \\
\hline 1-3 years & 3,68 &, 82 & 3,63 &, 78 & 4,08 &, 59 & 3,17 &, 88 \\
\hline 4-6 years & 3,43 &, 92 & 3,39 &, 79 & 4,07 &, 61 & 3,04 & 1,04 \\
\hline 7-9 years & 3,53 &, 74 & 3,49 &, 79 & 3,80 &, 77 & 3,09 & 1,04 \\
\hline 10 years and more & 3,78 &, 83 & 3,72 &, 77 & 4,10 &, 54 & 3,34 &, 85 \\
\hline
\end{tabular}

Source: Adapted from Akdeniz (2018, p. 177)

Term of employment in the institution revealed significant findings as a result of MANOVA. Firstly, it was observed that Managers' safety commitment and priority of safety averages are significantly lower for 4-6-year employees compared to $10+$ year employees (Pillai's Trace $=.09$, $\mathrm{F}_{(18,1533)}=2.52$, partial $\left.\eta^{2}=.03\right)$. This means the group with the longest term of employment, who probably have the highest level of experience, consider the management to be in charge or safety issues and doing their best, so they trust the management. However the group with comparatively shorter term of employment in this institution do not consider the management acting responsibly enough or taking safety as a priority, or in short not committed to safety adequately.

As for Safety training and communication the 4-6-year group revealed lower averages compared to the 1-3-year group and the 10-years and more group. This can be interpreted as the 4-6-year group do not perceive themselves trained enough in terms of safety and do not feel comfortable in terms of safety communication. The 1-3-year group is probably optimistic about their institution 
and they are expecting to get trained more and get better at safety communication in time. The 10years and more group is content with their training experience and safety communication abilities. As for Safety awareness and competency the 7-9-year group revealed statistically lower averages compared to all other groups and among other groups no significant difference was detected as a result of paired comparisons. This reveals that among the employees who have been working for this institution for 7 to 9 years there is a kind of need for specific safety training as apparently they do not perceive themselves competent and aware enough in terms of safety.

Finally, the 4-6-year group revealed lower averages in terms of Employees' Involvement compared to the 10-years and more group. This can be interpreted as the fact that the 4-6-year group would like to be involved in OHS activities and decision making process and are not content about the existing situation thereof. However, the 10-years and more group is content with the safety involvement opportunities they have.

As a result, the 4-6-year group have low levels of safety culture in terms of some dimensions. This may be interpreted as members of this group have unique experience concerning recruitment or safety trainings or workplace accidents. Their expectations concerning safety may be higher or they may not feel that they work in a good safety culture environment. Safety training and activities designed specifically for this group would work better for them instead of general regularly repeated trainings. On the other hand, group of 10-years, who are possibly the most experienced group, seem to have internalized the safety conditions of their institution and they consider all the conditions to be good enough.

Statistically significant difference was determined between the groups of duty at work as a result of MANOVA. The results are given in Table 6.

Table 6: Participants' Duty at Work and Safety Culture Dimensions

\begin{tabular}{llclc}
\hline & \multicolumn{2}{c}{$\begin{array}{c}\text { Safety awareness and } \\
\text { competency }\end{array}$} & \multicolumn{2}{c}{ Reporting culture } \\
\hline Duty at work & Mean & SD & Mean & SD \\
\hline Worker & 4,10 &, 58 & 3,78 &, 82 \\
\hline Administrative Personnel & 3,91 &, 61 & 3,50 &, 89 \\
\hline Manager & 4,10 &, 61 & 3,58 &, 96 \\
\hline Engineer & 3,82 &, 69 & 3,56 &, 87 \\
\hline
\end{tabular}

Source: Adapted from Akdeniz (2018, p. 177)

The participants' duty affected only two dimensions of safety culture: Safety awarenesscompetency and reporting culture (Pillai's Trace $=.04, \mathrm{~F}_{(18,1533)}=2.14$, partial $\eta^{2}=.02$ ). When the paired comparisons are considered it is observed that only the difference between the workers and the engineers is statistically significant in terms of Safety Awareness. The safety awareness of workers is significantly higher than that of engineers. This probably shows that the workers perceive themselves to be totally aware of the risks and danger in their workplace and they consider themselves to be competent enough to deal with all safety issues they might encounter. However, engineers do not perceive themselves competent enough to deal with the safety they might encounter.

The paired comparisons did not provide significant results for reporting culture. However, the workers seem to have comparatively higher perception in terms of Reporting Culture. 
Dursun (2012) determined that managers display higher means than the workers for dimensions of managers' safety commitment, priority of safety, safety communication, safety training and awareness, safety involvement and reporting culture. As for the Fatalism dimension, he determined that workers have significantly higher means than the managers.

Statistically significant difference was determined between the participants who have a near-miss accident experience and those who have no such experience as a result of the conducted t-test. The results are given in Table 7.

Table 7: Participants' State of Having Experienced a Near Miss Accident at This Institution and Safety Culture Dimensions

\begin{tabular}{|c|c|c|c|c|c|c|c|c|}
\hline \multirow[b]{2}{*}{$\begin{array}{l}\text { Experience of having a } \\
\text { near-miss accident in } \\
\text { this workplace }\end{array}$} & \multicolumn{2}{|c|}{$\begin{array}{c}\text { Managers' safety } \\
\text { commitment and priority of } \\
\text { safety } \\
\end{array}$} & \multicolumn{2}{|c|}{$\begin{array}{l}\text { Safety training and } \\
\text { communication }\end{array}$} & \multicolumn{2}{|c|}{$\begin{array}{l}\text { Employees' } \\
\text { involvement }\end{array}$} & \multicolumn{2}{|c|}{ Reporting culture } \\
\hline & Mean & SD & Mean & SD & Mean & SD & Mean & SD \\
\hline Yes & 3,44 & ,93 & 3,40 & ,83 & 3,05 & 1,04 & 3,59 & ,92 \\
\hline No & 3,72 & ,80 & 3,66 & ,75 & 3,25 & 87 & 3,79 & ,79 \\
\hline
\end{tabular}

Source: Adapted from Akdeniz (2018, p. 177)

The results of the $t$ test indicates that those who have experienced a near-miss accident have significantly lower managers' safety commitment and priority of safety values compared to the other group $\left(\mathrm{t}_{(335.58)}=-3.47, \mathrm{p}<.001\right)$.

As a result of the t test for safety training and communication it was determined that the averages of those who have experienced near-miss accidents are significantly lower than the other group $\left(\mathrm{t}_{(516)}=-3.66, \mathrm{p}<.001\right)$. This was an expected result, as it reveals that those who have any experience of accident would probably regard the management responsible before considering any mistake they might have made. The high levels of managers' safety commitment and priority of safety determined for this institution reveal high expectations of the employees from the management in terms of safety. However, the variables of having the experience of having an accident in this workplace or in any other workplace were not observed to have any statistically significant effect on safety culture dimensions, which was surprising.

$\mathrm{t}$ test results indicate that those who have experienced near-miss accidents have significantly lower scores in employees involvement $\left(\mathrm{t}_{(327.65)}=-2.28, \mathrm{p}<.05\right)$ and reporting culture $\left(\mathrm{t}_{(337.58)}=-2.47\right.$, $\mathrm{p}<.05)$ compared to the other group, which again reveals that those who have near-miss accident experience have lower level of safety culture in terms of employees involvement, reporting culture. Safety culture research carried out in different industries provided diverse outcomes regarding different demographic groups. The results offered in the present study and previous studies revealed some similar and different results. However, it would be possible to conclude that groups with different demographic qualities have different safety culture perceptions, which means it is beneficial to evaluate these differences while designing OHS procedures. At this point, human resources management and management science disciplines would support OHS professionals as they provide detailed analysis of critical data on the demographics. 


\section{Conclusion}

Culture is a strong factor in formation of human behaviour. In order to interpret the reasons lying under the unsafe behaviour of workers and to establish desired behaviour among the members of an organization, organizational culture could be a useful tool. In this context, for eliminating unsafe behaviour among workers, establishing safety as a priority and creating safe behaviour norms and focusing on safety culture in general would be very beneficial. Observing safety culture perception among the members of an organization on a regular basis thus determining any shortcomings in this aspect would give the OHS professionals valuable data to build their activities on. As a result, in order to improve safety performance of a company, OHS professionals should work with human resources department that will supply them with safety culture data.

This study is an example research applied at a large state owned coal mine institution, namely TKİGLİ. Considering high safety risks of mining industry and some positive features of the institution such as being a state owned and long-established coal mine with all its traditions, rooted culture and large experience in the industry TKİ- GLİ was a very good research population.

Results of the analyses revealed that the participants' safety culture levels have statistically significant difference for age, education level, work experience, duty at work, and the state of having been exposed to any near-miss accidents. However, no statistically significant difference was determined for their marital status, position at work, the state of having been exposed to any occupational accidents in any institution and the state of having been exposed to any occupational accident in this institution. These results, of course, could be different for different institutions, which means applying the same survey to other institutions would also bring along valuable findings for both the literature and the institutions themselves.

By this research, it was determined that in order to design safety training and other OHS activities concerning the employees, their demographic features and their needs should be determined beforehand. This is possible by simply applying a safety culture survey and finding out about perceptions of both managers and workers. Otherwise, the activities would be designed blindfolded. As seen in this study, different groups of employees can have different needs in terms of safety and by the help of specially designed trainings it would be more effective to treat certain groups with what they actually need. It was also determined that an organization might be strong in terms of some safety culture dimensions but it may be weaker in terms of others. Therefore determining strengths and weaknesses concerning safety culture would probably be useful for OHS experts for understanding the needs of their institution better.

In conclusion, first of all it is clear that there is a certain shortage of empirical studies concerning safety culture in Turkey. Literature reveals that analysing the organizational culture of the institutions would contribute to the solution of many organizational problems which stem from human factor. Prevention of occupational accidents is one of those problems. Therefore, number and quality of safety culture studies should be increased. As for enterprises and other organizations with high levels of risk, regular surveys checking the safety culture perceptions of the employers would definitely contribute the OHS efforts. This could be included in the human resources management activities.

Therefore, it should be stated that, OHS issues need contribution of many disciplines besides engineering such as human resources management, business administration, behavioural sciences 
and organizational behaviour. This need stems from the importance of human factor in workplace accidents and the reasons that lie beneath unsafe behaviour. Acknowledging significance of organizational culture and safety culture together with the power of culture on shaping behaviour would definitely contribute to the success of OHS efforts. Within an organization, identifying the present organizational and safety culture, evaluating its strengths and weaknesses and finally manipulating it for the purposes of the organization are duties of the administration and human resources department mainly. The more studies concerning safety culture and safety behaviour are carried out by scholars, the bigger success is possible in OHS efforts, which after all is quite a matter of human life.

\section{Acknowledgement}

This article was based on the data and analyses from Burcu Akdeniz's PhD Dissertation entitled "An Analysis of the Relationship Between Organizational Culture and Safety Culture in View of Occupational Health and Safety: a Study at a Mining Enterprise", supervised by Assoc. Prof. Dr.

Ceren GIDERLER at Dumlupinar University, Institute of Social Sciences, Department of Business Administration, Kütahya Turkey. A previous version of this article was presented at $7^{\text {th }}$ International Conference on Business Administration organised jointly by Çanakkale 18 Mart University and Silesian University on May 3-5, 2018 in Çanakkale, Turkey.

\section{References}

[1] AKDENIZ, B., 2018. Örgüt Kültürü ile Güvenlik Kültürü İlişkisinin İş Sağlığı ve Güvenliği Açısından İncelenmesi: Bir Maden İşletmesinde Uygulama (An Analysis of the Relationship Between Organizational Culture and Safety Culture in View of Occupational Health and Safety: a Study at a Mining Enterprise), PhD Dissertation, Supervisor: Assoc. Prof. Dr. Ceren GIDERLER, Dumlupinar University, Kütahya.

[2] AKPINAR, T., 2014. İş Sağlı̆̆1 ve İş Güvenliği, Ekin Basım Yayın Dağıtım, Bursa.

[3] ALLI, B. O., 2008. Fundamental Principles of Occupational Health and Safety, International Labour Office, Geneva.

[4] BAŞ, T., 2001. Anket, Seçkin Yayıncılık, Ankara.

[5] COOPER, M. D., 2001. Improving Safety Culture: A Practical Guide, Applied Behavioural Sciences, Hull.

[6] CHOUDHRY, R. M. and F. DONGPING, 2008. Why Operatives Engage in Unsafe Work Behavior: Investigating Factors on Construction Sites, Safety Science 46, pp. 566-584.

[7] CLARKE, S., 1999. Perceptions of Organizational Safety: Implications for the Development of Safety Culture, Journal of Organizational Behavior, No 20, Vol 2, pp. 185-198.

[8] COOPER, M. D., 2000. Towards a Model of Safety Culture, Safety Science, Vol. 36, Issue: 2, pp. 111-136.

[9] DEMİRBİLEK, T., 2005. Işs Güvenliği Kültürü, Legal Yayıncılık, İstanbul.

[10] DURSUN, S., 2012. İş Güvenliği Kültürü, Beta Yayınc1lık, İstanbul.

[11] DURSUN, S. 2013. İş Güvenliği Kültürünün Çalışanların Güvenli Davranışları Üzerine Etkisi, Sosyal Güvenlik Dergisi, Cilt 3, Sayı 2, pp. 61-75. 
[12] GELLER, E. S., 1994. Ten Principles for Achieving a Total Safety Culture, Professional Safety, 39 (9), American Society of Safety Engineers, pp. 18-25.

[13] GELLER, E. S., 2005, "Behavior-Based Safety and Occupational Risk Management", Behavior Modification, Vol. 29 No. 3, May 2005, pp. 539-561, Sage Publications.

[14] GLENDON, A. I. and N. A. STANTON, 2000. Perspectives on Safety Culture, Safety Science, Vol. 34, Issue: 1-3, pp. 193-214.

[15] GULDENMUND, F. W., 2000. The Nature of Safety Culture: A Review of Theory and Research, Safety Science, Vol. 34, pp. 215-257.

[16] HOFSTEDE, G., 1991. Culture and Organizations, Software of the Mind, McGraw Hill, New York.

[17] İRA, N. and A. AKSU, 2009. Örgütsel Kültür: Dokuz Eylül Üniversitesi Örneği, Dokuz Eylül Üniversitesi Buca Eğitim Fakültesi Dergisi, 25(2009), pp. 43-62.

[18] KILKIŞ, İ., 2014. İş Sağglı̆ ve Güvenliği, Dora Yayınc1lık, Bursa.

[19] KOÇEL, T., 2011. Işsletme Yöneticiliği, Beta Yayıncılık, İstanbul.

[20] KOZLU, C. 2013. Kurumsal Kültür: ABD, Japonya ve Türkiye'de Başarılı Şirket Yönetimleri, Remzi Kitabevi, İstanbul.

[21] LIN, Si-Hao; W. J. TANG, J. Y. MIAO, Z. M. WANG and P. X. WANG, 2008. Safety Climate Measurement at Workplace in China: A Validity and Reliability Assessment. Safety Science, 46, pp. 1037-1046.

[22] PALA, K., 2005. İSG Politikası ve Güvenlik Kültürü, İş Sağllğı ve Güvenliği Dergisi, Say1 25, Y11 5, pp.. 18-22.

[23] POTTER, D. L., 2004. Organizational Culture and Safety: Creating a Workplace with Safety as a Core Value http://www.carlpotter.com/admin/files/files/Safety\%20as\%20a\%20Core\%20Value.pdf.

[24] SAUJANI, M., 2016. World Class Safety Culture: Applying the Five Pillars of Safety, Professional Safety, pp. 37-41.

[25] SMITH-CROWE, K., M. J. BURKE and R. S. LANDIS, 2003, Organizational Climate as a Moderator of Safety Knowledge-Safety Performance Relationships, Journal of Organizational Behavior, Vol. 24, pp. 861-876.

[26] STEPHAN, S., 1999. Improving Your Mine's Safety Culture- the Ultimate Objective of the Safety Management System, Queensland Mining Industry Health and Safety Conference Proceedings, pp. 72-82.

[27] TÜZÜNER, V. L. and B. Ö. ÖZASLAN, 2011. Hastanelerde İş Sağlı̆̆ı ve Güvenliği Uygulamalarının Değerlendirilmesine Yönelik Bir Araştırma. İstanbul Üniversitesi İsletme Fakültesi Dergisi, Cilt/Vol:40, Sayı/No:2, 2011, pp.138-154, ISSN: 1303-1732. 